\title{
ECONOMY-WIDE IMPACTS OF INTERFUEL SUBSTITUTION: SUBSTITUTION OF ELECTRICITY FOR IMPORTED OIL
}

\author{
RAYMOND G. TESSMER, JR., AND JOAN LUKACHINSKI
}

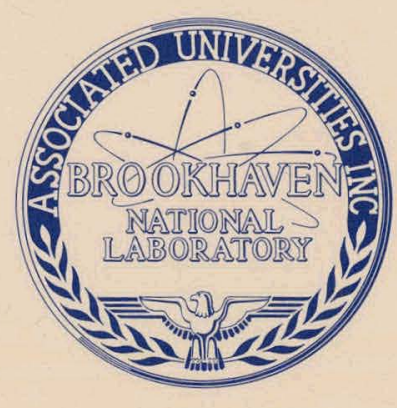

June 1976

Prepared for the

OFFICE OF THE ASSISTANT ADMINISTRATOR FOR PLANNING AND ANALYSIS UNITED STATES ENERGY RESEARCH AND DEVELOPMENT ADMINISTRATION by the ECONOMIC ANALYSIS DIVISION, DEPARTMENT OF APPLIED SCIENCE

BROOKHAVEN NATIONAL LABORATORY ASSOCIATED UNIVERSITIES, INC. UNDER CONTRACT NO. E(30-1)-16 WITH THE UNITED STATES ENERGY RESEARCH AND DEVELOPMENT ADMINISTRATION 


\section{DISCLAIMER}

This report was prepared as an account of work sponsored by an agency of the United States Government. Neither the United States Government nor any agency Thereof, nor any of their employees, makes any warranty, express or implied, or assumes any legal liability or responsibility for the accuracy, completeness, or usefulness of any information, apparatus, product, or process disclosed, or represents that its use would not infringe privately owned rights. Reference herein to any specific commercial product, process, or service by trade name, trademark, manufacturer, or otherwise does not necessarily constitute or imply its endorsement, recommendation, or favoring by the United States Government or any agency thereof. The views and opinions of authors expressed herein do not necessarily state or reflect those of the United States Government or any agency thereof. 


\section{DISCLAIMER}

Portions of this document may be illegible in electronic image products. Images are produced from the best available original document. 


\title{
ECONOMY-WIDE IMPACTS OF INTERFUEL SUBSTITUTION: SUBSTITUTION OF ELECTRICITY FOR IMPORTED OIL
}

\author{
RAYMOND G. TESSMER, JR., AND JOAN LUKACHINSKI
}

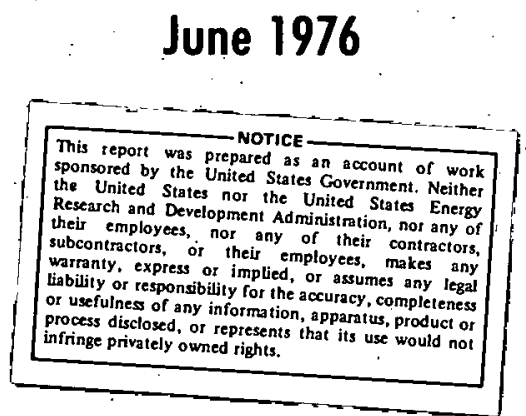

Prepared for the

OFFICE OF THE ASSISTANT ADMINISTRATOR FOR PLANNING AND ANALYSIS UNITED STATES ENERGY RESEARCH AND DEVELOPMENT ADMINISTRATION by the ECONOMIC ANALYSIS DIVISION, DEPARTMENT OF APPLIED SCIENCE

BROOKHAVEN NATIONAL. LABORATORY UPTON, NEW YORK 11973 


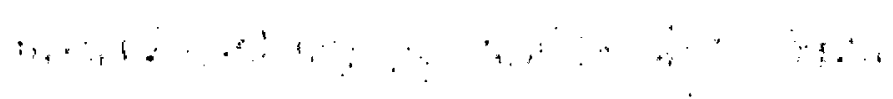

$$
\because \because 1 \rightarrow \cdots
$$

\section{N O T I C E}

This report was prepared as an account of work sponsored by the United States - Government. Neither the United States nor the United States Energy Research and - Development Administration, nor any of their empluyees, nor any of thcir contractore, Eubcontractors, $n r$ theiremplnyees, makes any warranty, express or implied, or assumes any legal liability or responsibility for the accuracy, completeness or usefulness of any information, apparatus, product or process disclosed, or represents that its use would not infringe privately owned rights.'

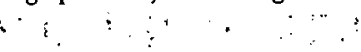

Printed in the United States of America $\Lambda$ vailable from

National Technical Information Service

U.S. Department of Commerce 5285 Port Royal Road Springfield, 'VA' 22161

: Price: Printed Copy $\$ 4.50$; Microfiche $\$ 2.25$ 


\section{Abstract}

An Energy Input-Output Model is applied to analysis of the long run effects (to 1985) of higher oil prices in the U. S. economy. Two questions are examined. First, what are the effects of sustained, higher international oil prices? Second, what are the effects of substituting domestic coal--produced electricity for high-priced foreign oil. Variables examined include capital investment; personal consumption expenditures, exports and imports, labor force, and energy production. 


\section{Executive Summary}

A new analytic tool -- the Brookhaven/University of Illinois Combined Energy Optimization/Input-Output Model -- has been applied to an analysis of the long run effects (to 1985) of higher oil prices in the U.S. economy. Case I with $\$ 5.35 / \mathrm{Bbl}$. oil (in 1967 dollars) is compared to Case II with $\$ 10.70 / \mathrm{Bbl}$. oil and no constraint on oil imports. Case III with $\$ 10.70 / \mathrm{Bbl}$. oil and sharply curtailed oil imports is then compared with Case II. An earlier, Brookhaven study examined the same question with the more limited Brookhaven Energy System Optimization Model as an analytic tool. With the richer content of the combined model, the fullowing 1985 cconomy-wide effects have hesn lântifiel:

- Capital Investment

Case II vs. Case I - $1.7 \%$ more $(\$ 202.4$ billion

for Case II)

Case III vs. Case II - $3.7 \%$ more ( $\$ 209.9$ billion for Case III)

- Personal Consumption

Case II vs. Case I. - $1.5 \%$ less

Case III vs. Case II - $0.8 \%$ less

- Exports

Case II vs. Case I - $7.5 \%$ more

Case III vs. Case II - $7.0 \%$ less

- Labor Force in Energy Sectors

Case II vs. Case I - 10.4\% more

Case. III vs. Case II - $11.0 \%$ more.

Most of the increase in capital investment provides greater capacity for the production of coal and electricity as domestic electric energy is substituted for imported oil. Coal production is $31 \%$ larger and electricity production is $16 \%$ larger in Case II than in case I. Case III shows 30\% greater coal output and $19 \%$ greater electricity output than Case II. In Case II there is also greater investment in exporting industries to pay for the more costly oil imports. Increases in investment of this order would most likely have major impact on capital markets (pp. $19-23)$. 
The additional investment occurs at the expense of personal consumption expenditures (standard of living). While this impact seems small, it is on the order of one year of per capita income growth based on recent growth trends (pp. 19-23).

Finally, the study shows a marked reallocation of labor to the energy producing areas. Both labor and output are lower. in consumer oriented industries and in food and food products ana medical and educational services (pp. 34-36).

An additional contribution of the combined model is the new estimates of total energy demand based upon a consistent treatment of economy-wide economic growth. Preliminary findings are that prior energy demand projections seem to be too large (pp. 24-27).

The study results in a set of recommendations directed to improving energy analysis tools. Perhaps the most important is :

"The difference in energy product demands predicted by the energy I-O model and those specified in "Sourcebook for Energy' Assessment" (commonly used energy demand projections) should be reconciled and definitional differences identified and recorded." (p. 37).

Although this is primarily a report on a combined model application, a further methodological development that is not reported on elsewhere is incorporated in Appendix B. This is a technique for estimating capital investment requirements. It will be used in conjunction with the combined model until superseded by the use of a full capital coefficient matrix. 
Table of Contents

Page

I. Summary of Findings " 1

II. Methodology and Assumptions 6

A. Description of Comined Energy 7

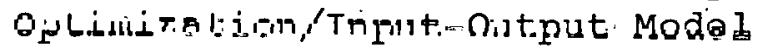

III. Results $\quad 19$

A. Gross National Product 19

B. Demand for Energy. 24

C. Capital Investment $\quad 28$

D. Composition of Output in the Non- 31 Energy sectors

E. Employment Distribution 34

IV. Recommondations . . 37

Roferences . 39

Appendix A Combined Model Input Data and 40 Output

Appendix B Estimation of Capital Investment 49 Requirements

Appendix C GNP standardization I'echniques 53 


\section{SUMMARY OF FINDINGS}

Short-run impacts of reduced availability of Arab oil during the embargo of 1973-1974 and of the subsequent large price increases have been experienced by the entire U.S. economy. The long run effects of higher prices and policies aimed at decreased dependence on imports are not clear. In this report two major policy questions are evaluated in terms of their long-run impact on the structure of the nation's economy:

1) If the higher oil price initiated by the organization of Petroleum Exporting Countries persists over the next ten years, how will the structure of the economy change?

2) Given the higher price of oil, what will be the further effect on the economy of U.S. policies designed to reduce oil imports below that level resulting from the price increase alone?

In anower to the firsl question, this study tinds that a doubling of oịl price to $\$ 10.70 /$ barrel ${ }^{*}$ will result in an increase of $\$ 3.4$ bilion, or $1.7 \%$ in 1985 annual capital equipment expenditures over the capital expenditures with $\$ 5.35 / \mathrm{bbl}$ oil. This capital will be emplaced in the coal and coal steam electric generation sectors of the economy as

\footnotetext{
*All data is presented in constant 1967 dollars.
} 
electricity is substituted for direct combustion of oil products, assuming limitations on domestic capacity for crude oil and nuclear electricity production. On an average annual basis, capital equipment requirements between 1967 and 1985 will increase from a $3.2 \%$ to a $3.3 \%$ rate of growth.

The production of consumer goods and services will be $\$ 13.8$ billton or $1.5 \%$ smaller ag resources are realloraten to the increased production of capital youds and gooda for. export. This represents a substantial change in the rate of grointh of the standard of living for Anericans: 0 an an average annual basis, this means an annual growth rate of $3.7 \%$ instead of $3.8 \%$ as a result of higher priced oil. Uader the assumption of $100 \%$ recycle of petrodollars, one can also expect the demand for U.S. export.goods to increase by $7.5 \%$.

1) Doubled Oil Price Results

$$
\begin{gathered}
\text { absolute change, change in mean } \\
\text { billions of dollars annual growth rate, } \\
1.967-1.985
\end{gathered}
$$
Capitàl Investment
$+\$ 3.4$
from $3.2 \%$ to $3.3 \%$
Consumer Goods \& Services
$-\$ 13: 8$
from $3.8 \%$ to $3.1 \%$
Exports
$+\$ 7.5$
from $5.8 \%$ to $6.2 \%$

Non-energy sectors which will experience the greatest percentage increase in output' as a direct result of OPEC̣'s high oil price policy are water transportation and iron. and ferroalloys ore mining. Non-energy sector increases in 
employment will be greatest in new construction, other agricultural products, and general industrial equipment. Reductions in employment will be greatest in food and kindred products, wholesale and retail trade, and medical and educational services.

In answer to the second question this study finds that a $42 \%$ reduction in oil imports will increașe 1985 capital equipment expenditures by an additional $\$ 7.5$ billion, or 3.7\%: Such an increase in the demand for capital is large enough to affect the cost of capital within the capital market: Increase in capital requirements will again be greatest in the coal and coal steam electric generation sectors. Einployment in the energy sectors as a whole will increase $11.0 \%$ to 2.3 million man-years.

With a decrease in petrodollar expenditures to foreigners of $\$ 15$ billion, demand for U.S. exports will be as much as $\$ 7.5$ billion less. Production of consumer goods and services could be as much as $\$ 7.5$ billion lower, or sliglily under $1 \%$ of personal consumption expenditures, because of the greater production of capital.goods. (Considering the combined impact of higher oil prices and restricted oil imports, reduction in personal 
consumption expenditures could be as great as $\$ 21.3$ billion, or $2.3 \% !)$

2) Reduced Oil Imports Results

$\begin{array}{lrl} & \begin{array}{c}\text { Absolute change, } \\ \text { bilions of dollars change in mean } \\ \text { annuli growth rate, } \\ 1967-1985\end{array} \\ \text { Capital Investment } & +\$ 7.5 & \text { from } 3.3 \% \text { to } 3.5 \% \\ \text { Consumer Goods \& Services } & -\$ 7.5 & \text { from } 3.7 \% \text { to } 3.6 \% \\ \text { Exports } & -\$ 7.5 & \text { from } 6.2 \% \text { to } 5.8 \%\end{array}$

Non-energy sectors which will experience the greatest percentage increase in output as a direct result of. restricted oil imports include most construction and capital goods sectors. The largest percentage decreases will appear in the water transportation and pipeline transportation sectors. The greatest increase in non-energy employment will occur in new construction and capital goods sectors. The greatest decrease will occur in wholesale and retail trade and in medical and educational services.

One additional finding comes from this application of Brookhaven's energy input-output model. The composition of energy demands for 1985 as forecast by the $\dot{I}-0$ are somewhat different from the forecasts presented in "Sourcebook for Energy Assessment" (1), a standard reference document. The I-O 
calculates energy demands in the framework of a realistic. constraint placed by Gross National Product on 1985 productive capacity of the country. The Sourcebook projects demands on the basis of judgemental growth rates applied to each demand category. If further study indicates that the I-O coefficients are not in error, the I-O technique can now be used to provide high confidence energy demand projections. 


\section{METHODOLOGY AND ASSUMPTIONS}

The central question addressed by this report is, What

will be the economy-wide impacts of higher oil prices and reduced oil imports over the long run? Within the energy sector, probable impacts have been analyzed in the report, "Interfuel substitution Study - The Role of Electrification," or, as it is referred to here, the Electrifiration Study. (2) Long-run adjustments that can be expected include development and pruduction of oynthulde: fuels, an increase in the use of coal, and increased substitution of electricity and electrical end-use devices for direct combustion of fuels (i.e. substitution of heat pumps for oil-fired furnaces). Such changes were estimated with the assistance of a linear programming (LP) optimization model of the nation's energy system, which is described in (10).

Important as these changes are, there are effects outside the energy sector that can not be investigated with the optimization model alone. What, for instance, might be the effect of higher priced oil imports on the country's international balance of payments? Or what would be the effect of higher capital spending in the energy sector on production of consumer goods and services?

In order to analyze economy-wide effects of changes in 
energy prices and technology, a new analytical tool has been developed - a Combined Energy Optimization/Input-Output Model of the U.S. economy, the I-O. This model, which is a combination of the linear program energy optimization model with a standard input-output model, is employed in this analysis of increased substitution of electricity for imported oil. Two cases from the Electrification study are analyzed along with a case with even more drastic reduction in oil imports. Comparison of case II with Case I and of Case III with Case II are of special interest. The first comparison looks at the question, "What happens if the oil cartel is able to maintain their higher price for oil over. the next ten years?" The second comparison looks at the guestion, "Given that higher oil prices do prevail, what are the effects of policies which will cut oil imports drastically by 1985?"

Discussion of results concentrates on those findings from the I-O model that were not determinable with the r.P model alone. A detailed discussion of the nation's energy system configuration is not presented as this has already been done in the previous study.

A. Description of Combined Energy Optimization/Input-Output Model This specialized input-output model of the national 
economy has been developed in collaboration with the center for Advanced Computation of the University of Illinois and is described in detail in (6). A significant feature is that the output of the energy sectors is not measured in dollars but in BTU's of raw coal, crude oil and gas,. refined petroleum products, pipeline gas, and generated electricity. The output of these sectors, termed energy supply/conversion sectors, is not distributed directly to other sectors of the economy. Astide from distribution of fuels among these sectors, * their output is distributed to eight dimmy energy product sectors defining nonsubstitutable end-use demands for energy--coke, petrochemical feedstocks, motive power, process heat, water heat, space heat, air conditioning, and electric porner (7).

Energy input to non-energy sectors is respecified in terms of these functional energy products rather than in terms of generated electricity and specific fuels such as coal or natural gas. By specifying input requirements in terms of energy products such as process heat, substitution among fuel supplies is permitted, and an invariant production function tor non-cmergy sectuss suffices. Tcchnological. change asspciated. with fuel substitution is localized in the *All crude oil and gas output goes to either the refined petroleum products sector or to the pipeline gas sector, and a portion of the coal output goes to the electric generation/ distribution sector, for example. 
production functions of energy. supply/conversion sectors.

The revised input-output coefficient of production matrix is depicted in Figure 1. It is based on the Bureau. of Economic Analysis (BEA) input-output table for 1967 with 78 regular producing sectors.(8) Outputs of the energy supply and energy product sectors are measured in physical units, British Thermal Units (Btu), and outputs of the nonenergy sectors are measured in dollars. 'Production coefficients in the $A_{S S^{\prime}} A_{S P^{\prime}}$ and $A_{P S}$ submatrices have units of $B t u / B t u$, in the $A_{P I}$ submatrix Btu/s, in the A ${ }_{\text {IS }}$ submatrix $\$ / B t u$, and the $A_{I I}$ submatrix $\$ / \$ .{ }_{P P}$ and $A_{I P}$ coefficients. are zero because energy product sectors are dummy, nonproductive sectors. The A SI $_{\text {S }}$ coefficients are zero because sectoral energy use is described in terms of final energy products via the $A_{P I}$ and $A_{P S}$ coefficients.

The BEA input-output table for 1967 contains five energy supply/conversion sectors: coal, crude petroleum and gas, refined petroloum producto, natural gas ulililies, and - electric utilities. In this model the electric sector is disaggregated on the basis of fuel used--fossil fuel, nuclear, and hydroelectric. In addition, input-output coefficients for six new energy technologies, as developed by the MITRE Corporation, McLean, Virginia, have been incorporated: Their 


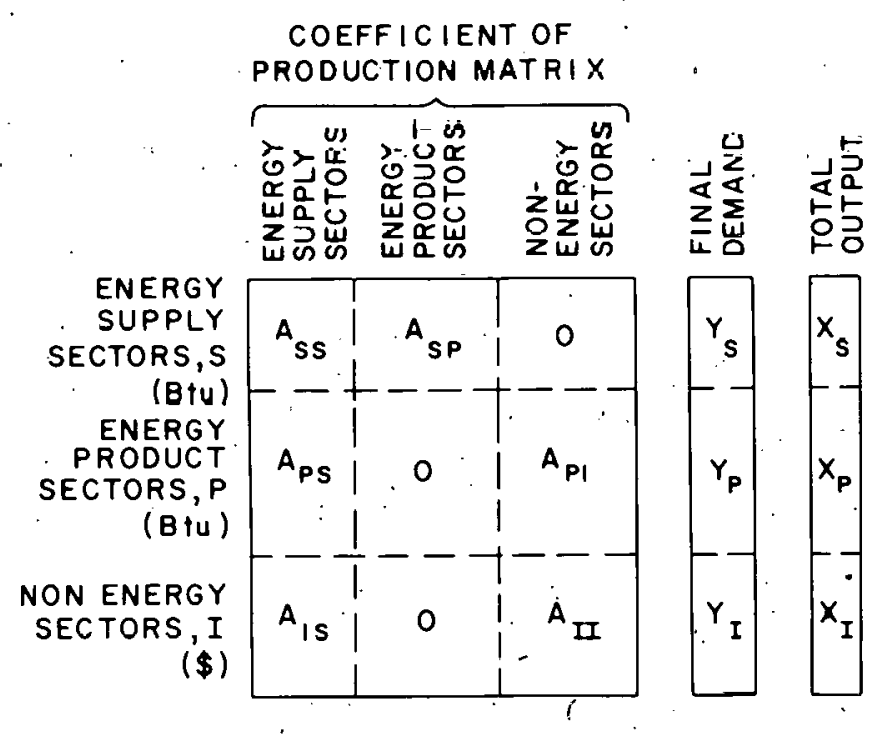

Figure 1. Energy input-output model. 
derivation is described in. (4). These technologies are the solvent refined coal process, for low sulphur, ashless coal production, mining and retorting of shale oil, the high temperature gas cooled reactor, high Btu coal gasification, low Btu coal gasification with the combined lo' Btu coal gas and steam cycle electric generation plant, and the light. water reactor. Data used to develop input-output coefficients of production were, for the most part, taken from detailed engineering cost studies of these new technologies.

The model is specified in such a manner that fuel substitution effects in the energy supply/conversion sectors can be reflected by coefficient changes within only the A ${ }_{S}$ S and $A_{S P}$ submatrices. These coefficients are, in turn, estimated from solution of the energy optimization model, the LP.

Figure 2 depicts the solution sequence for the combined model pictorially. The interface between the models consists of two sets of equations: one calculating demand constraints for the linear programing model from the total outputs determined by the I-O, and the other calculating input-output coefficients from the solution to the energy optimization model. They are described in (9) for the 110 sector model used in this analysis. 
Policy variables within the combined model include energy supply, capacity, environmental and other energy model constraints; the input-output $Y$ vector of final demand; and certain. A matrix coefficients, particularly eriergy product coefficients which can be changed to reflect energy conservation by producing sectors. The $Y$ vactor of final demand, representing Gross National Product, is actually an agyregation of eight componentss personal consumption expenditures, gross private fixed capital formation, net inventory change, exports, imports, federal government defense, federal gövernment non-defense, and state/local government. Policies affecting the detailed composition as well as aggregate level of GNP can thus be analyzed. 


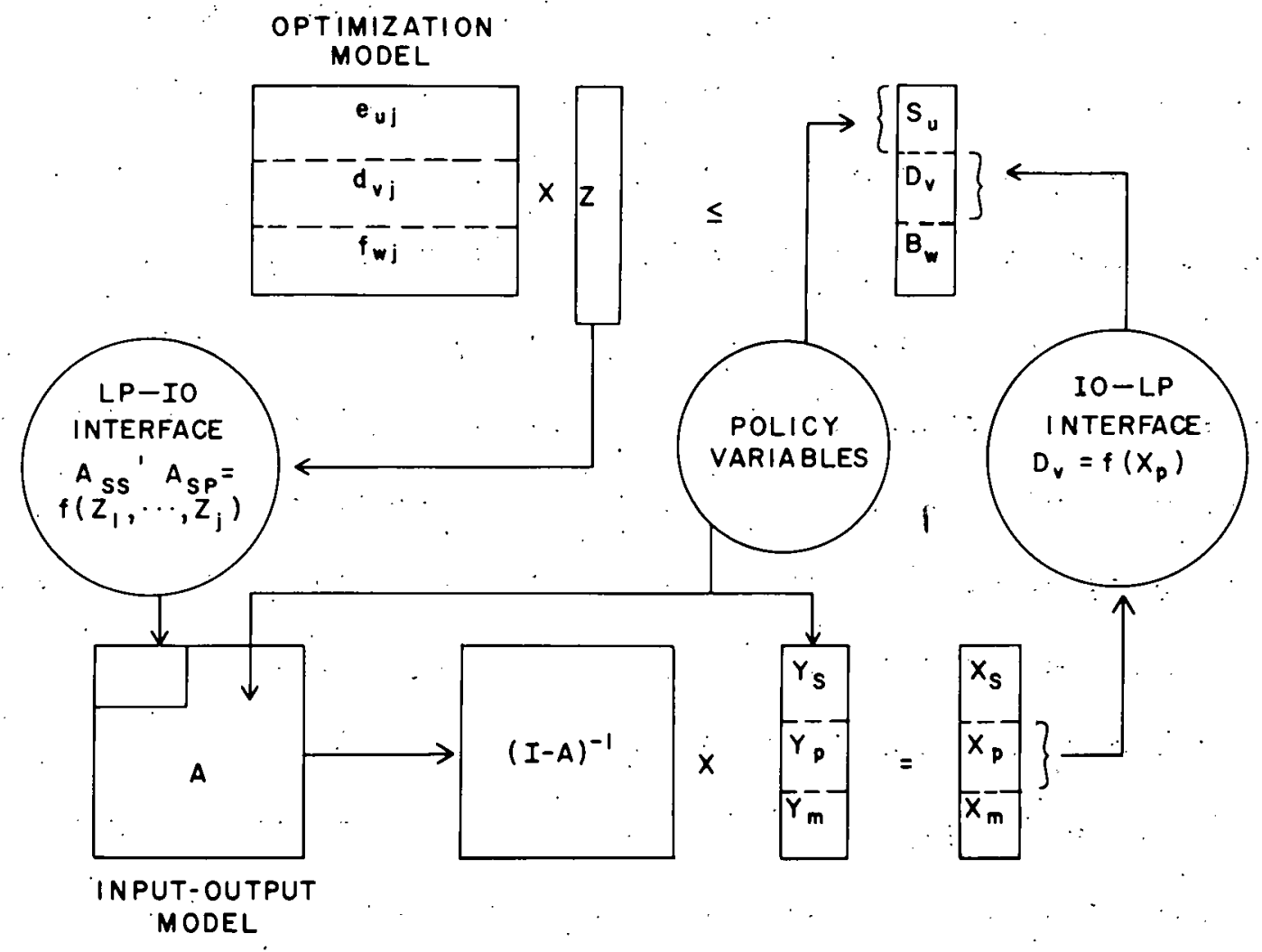

Figure 2. Solution sequence. 
Combination of the LP and the I-O nodels reduces the a priori judgments that must be made before running either model. With the input-output model one no longer must specify $A_{S S}$ and $A_{S P}$ coefficients; those which describe fuel flows and conversion into end-use energy products. These become determinable from an optimization model solution. With the optlmizatiun model one no longer must sperify total demands for energy products. Inslead, only thosc portions which comprise final demand in an input-output sense, i.e., that which is included in compilation of GNP, must be predetermined. Interindustry (sectoral) input demands for energy products are obtained through solution of the I-O. At the present time this two-level model is solved by iteration. The solution sequence, is as follows:

1. Develop a projected final demand vector for the I-O representing GNP for the planning year being analyzed. Insert estimated costs, capacities, resource availability, and other constraints for this planning year into the energy optimization model.

2. Rin the I-O modal to determine the Basic Energy Demands, or total outputs of: the eight energy product sectors, associated with the GNP projection. $A_{S S}$ and $A_{S P}$ coefficients can start out equal to zero, or appruximate values can be inserted to reduce running time to convergence. 
3. Disaggregate Basic Energy. Demands for motive and electric power to obtain (along with the other basic-epnergy demands) demand equation constraints for the optimization model:

4. Run the optimization model with disaggregated energy product demands to determine energy supply-demand configuration, the set of $\dot{z}_{j}$, energy flows.

5. Convert energy optimization model output to $A_{S S}$ and ${ }_{\text {AP }}$ coefficients and insert these into I-O model.

6. Perform iterative runs, testing for convergence of Basic Energy Damands after each iteration.

B. Assumptions.

Three cases are analyzed in this report. Case. I corresponding to the Base case of the Electrification study (2); Case II corresponding to Case II of the Electrification Study. (doubled oil price); and Case III which is the same as Case II except that oil imports are half the level of Case I.

Optimization nodel parameters and prices used in this study for Cases I and II correspond respectively.with those used in the Electrificialiun study Base case and case II. An oil price of $\$ 5.35 /$ barrel is assumed in Case $I$ and of $\$ 10.70$ for Cases II and III (in 1957 dollars).*

*These are equivalent to $\$ 6.17$ /barrel and $\$ 12.34 / \mathrm{barrel}$ in 1970 doliars, all prices in the optimization model being. expressed in constant 1970 dollars. 
Supply constraints correspond exactly in Cases. I and II. except for several new energy technologies which are not specified in the I-O model. As shown in Table A-1,.. Appendix A, coal combined-cycle capacity is substituted for oil combined-cycle, and additional pipeline-quality coal gas is substituted for hydrogen from coal: Solar electric and methanol from coal capacities are sct equal to zero since these two did not enter into Base Case or Case II solutions in the Electrificalion study. In Casc I of this study, imported oil is constrained to the solution value in the Electrification Study, $21.75 \times 10^{15}$ BTU, (10.6 million barrels/day), in order to achieve correspondence between the two analyses. In Case II, domestic oil is constrained to the solution value for Case. I, $20.59 \times 10^{15}$ BTU (10 million barrels/day), permitting decreased oil usage to reduce oil imports. In case III imported oil is constrained at half the level of the other cases, $10.88 \times 10^{15}$ BTU (5.3 million barrels/day). Domestic oil supply is increased over the first two cases in order to get a feasible LP solution. Because the potential for substituting electricity for oil is limited within a 1985 time framework, some minimum quantity of oil must be available if there are to be no serious disruptions or constraints in the national energy system.

Optimization model demand constraints are not prespecified 
in this study as they were in the Electrification Study. They come directly from the I-O solution vector of total energy product sector outputs. These demands directly reflect overall economic activity. This, then, is the major difference in how the LP model is set up in the two studies.

The basic assumption of the input-output model is longterm economic equilibrium. Sectoral growth rates for the planning year being analyzed are presumed to be equilibrium rates with no constraints placed on output of non-energy sectors. Concurrently it is assumed that resources of production are perfectly mobile over the long run and that price expectations for any scenario or case persist long enough for full reallocation of factors of production to occur.

Derivation of the 1985 estimated GNP and coefficients of production which are used in this analysis is presented in (3). The assumptions for labor force, manpower requirements per unit of output, and capital requirements per unit of output which lie behind the GNP estimate do not change for the three cases analyzed. This means that a constant real GNP is asșumed: The structure of the 1985 GNP purchases, however, is not held constant. It is this shift to production of export and capital goods and away from 
consumer goods and services resulting from lower oil imports that is analyzed. Other less likely economic adjustments can be postulated and analyzed. For example, one could analyze the effect of greater labor force participation or underemployment if there is reason to believe these might result from higher oill prices or lower imports. For simplisity, specific price elasticities for each final energy product are not assumed; thus, use of energy products by each sector per unit of output doas not change as oil price and relative energy product prices shift. although the mix of fuels supplying those products may shift.: Under these assumptions of long-run equilibrlum adjust ment, the input-output model provides a picture of alterna-: tive production and consumption patterns in the econony of 1985 . Detailed results are presented in the following sections. 


\section{RESULTS}

A. Gross National Product

The value of 1985 Gross National Product (GNP) assumed in this analysis is $\$ 1439$ billion (in 1967 dollars),* or a growth rate of $3.4 \%$ per annum from 1967 to 1985. The basis for this estimate is presented in (3). This estimate of aggregate real GNP was used for all three cases in order to standardize on single values for the labor force, labor productivity, and capital produstivity。

Although real GNP in the aggregate is the same, individual components** in the disaggregate vary among the three cases. Several factors account for this shift in the production of final goods and services。 First, higher payment to foreigners for more expensive oil means that more export goods must be produced and/or fewer goods imported in order to maintain balance of payments equilibrium. Second, substitution of domestic for foreign energy supplies means that more capital goods must be produced to support higher levels of domestic production, under the assumption of fixed capital/ output ratios. Finally, increased output of export and capital goods in turn shifts production away, from goods and services that are consumed by individuals and/or government.

*'l'his is equivalent to $\$ 1220$ billion in 1958 dollars.

**GNP purchases are divided into eight components: personal consumption expenditures, gross private fixed capital formation, inventory change, federal government defense expenditures, federal government non-defense expenditures, state and local government expenditures, exports, and competitive imports. 
Table 1 shows shifts in the GNP components as oil imports are reduced, under the assumptions described in Appendix $C$. The driving force, of course, is the decrease in crude oil and refined oil imports. Expressed in real terms, competitive imports are $4.7 \%$ less for Case II and, for Case III, $12.9 \%$ less than for cāse II.

The immediate impact on GNP is that more capital goods must be produced to provide additional domestic productive capacity in coal mining, coal-fired electric generating plants, shale oil, pumped storage plants, and certain other industries. In the aggregate, capital investment must be greater by $\$ 3.4$ billion, or $1.7 \%$, in Case II over Case I and by another $\$ 7.5$ billion, or $3.7 \%$, in Case III over Case II to support necessary domestic energy production.

Because total dollar payments for imports are the same in Case I and case III (doubled oil price, but hdif the quantity), it is assumed that balance of payments effects in the aggregate are negligible. Exports are therefore assumed to be the same for these two cases. In case II, on the other hand, total dollar payments for imports increase because oil doubies in price while oil imports fall buly l4k. As described in Appendix $C$, the increase in dollars held by foreigners 
Table 1

Components of 1985 GNP in Real Terms

(Billions of 1967 Dollars)

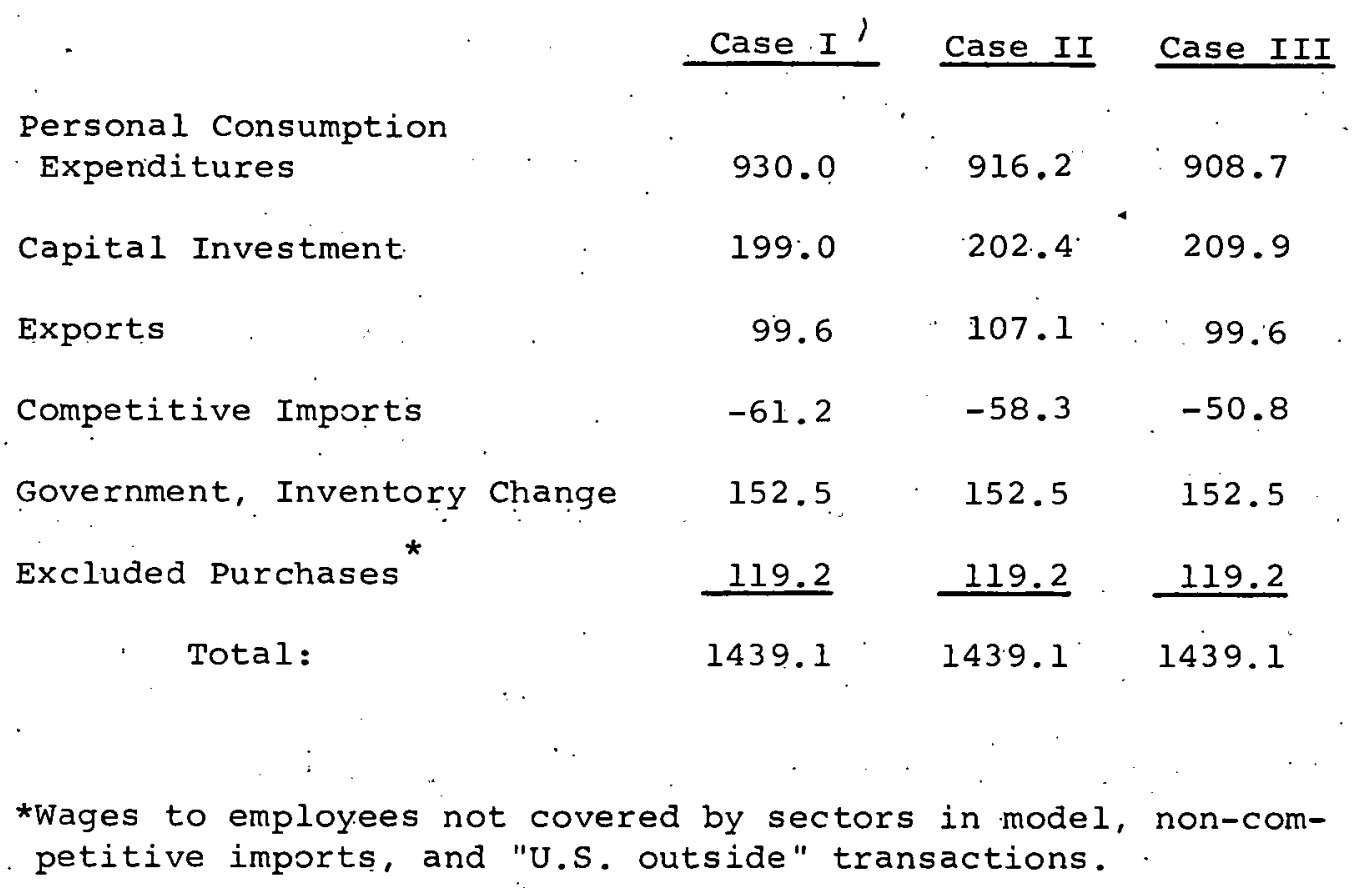


generates a $7.5 \%$ increase in the demand for exports through a drop in the value of the dollar relative to foreign currencies. Finally, the increase in net exports and capital goods production draws resources away from the production of other consumption goods and services. Assuming that the full effect takes place in personal consumption expenditures in lieu of government purchases, inventory change, and excluded purchases, the following significant effects take place. In edse II pergonal consumption expenditures drop by $1.5 \%$ and in Case III by another $0.8 \%$ over Casé $I$. In addition to a change in the standard of living; these necessary changes in composition of GNP have significant effects on the composition of domestic production and employment, which are described in detail in the following sections of this report.

Table 2 summarizes the shift in relative GNP shares for the three cases. Mean annual rates of growth from 1967 to 1936 are shown for four of the eight GNP components. Most significant is: (1) the increase in capital investment from an annual growth rate of $3.2 \%$ in case I to $3.3 \%$ in case II and to 3.5\% in Case III; and (2) the decrease in PCE from $3.8 \%$ annual growth in Case $I$, to $3.7 \%$ in Case $I I$ and $3.6 \%$ iil Case $I \perp 1$. 
TABLE 2

COMPARISON OF MEAN ANNUAL RATES OF GROWTH FOR SELECTED GNP COMPONENTS

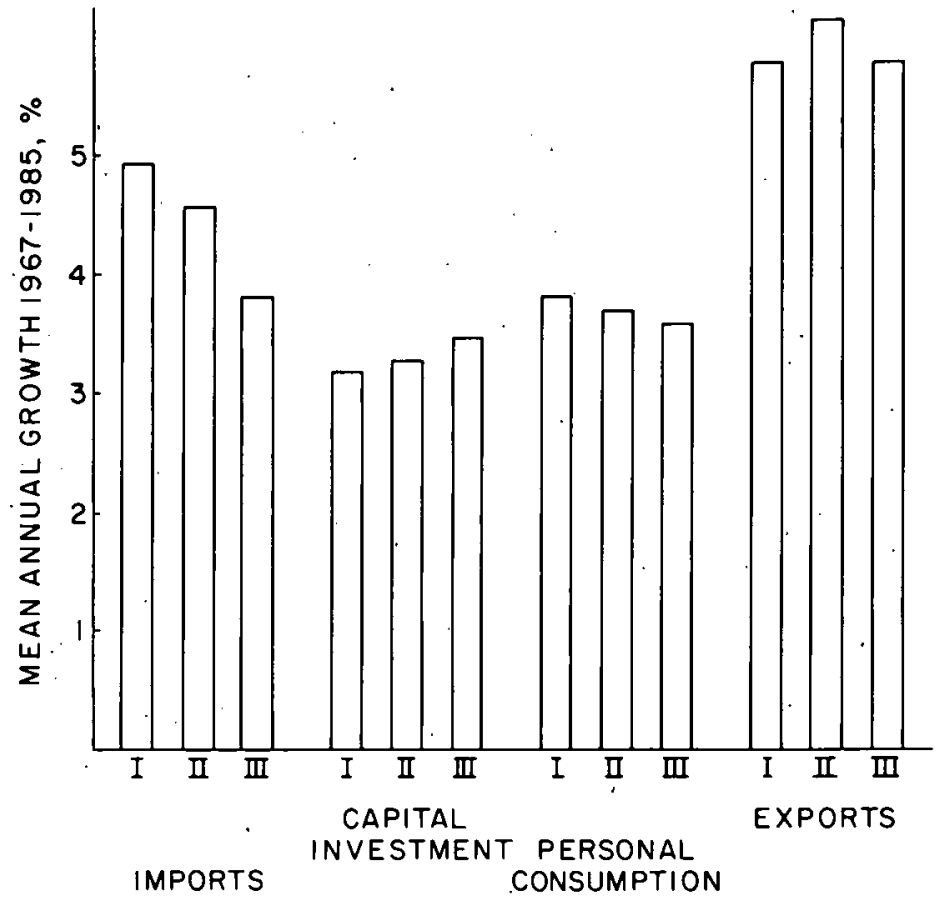




\section{B. Demand for Energy}

Within an input-output model framework, demand for energy can be partitioned into two components - interindustry demand by producing sectors of the economy, and final demard by consumers and goverument as counted in Gross National Product. To use the I-O model only that portion of total dcmand includer in GNP must be prespecified, about 30\%. The other $70 \%$ depends on the GNP bill of other goods and services prespecified and the industrial processes used to produce them. Techniques for estimating a future GNP and its components are highly developed, and considerable confidence can be placed in them.

In the form used for this study, with energy demand specified in physical units (BTU), the approximate proportion of each total energy demand prespecified is shown below in Table 3 .

Table 3. Exogenously Specified Energy Demands
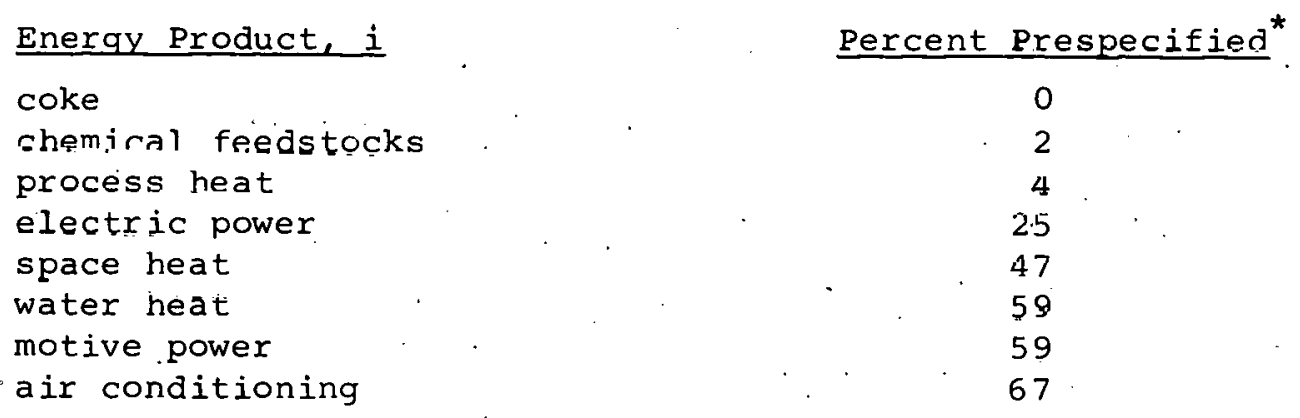

"Flyures are prescntod for the Case I solution. The proportion of each demand that is determined within the model is found by subtracting the amount prespecified in the aggregate vector of final demand, $Y_{i}$, from total output of an energy product sector, $x_{i} \cdot$ ' 
Significantly, virtually all of the demand for coke,

chemical feedstocks, and process heat is endogenously determined

by the model. And three-fourths of the demand for electric power

is endogenously determined. This is in sharp contrast. with the

optimization model when it is used without.the I-O. Then

the entire demand for energy must be estimated and prespecified

for the economy.

Table 4 lists total demands as determined by the three

runs of the combined model and compares them with earlier es-

timates from the Sourcebook* (1) and the Electrification Study (2).

Demand estimates differ significantly in the latter two studies,

those in the Sourcebook being more recent. Comparing Sourcebook

estimates with the combined model solutions, correspondence in

the demand for coke, motive power, air conditioning and electric

power is fairly close. Differences for the other energy products

are greater because of variation in definitions and assumptions

among the studies and because the earlier studies had no over-

all demand constraint based on productive resomrces of the economy.

The much larger demand for space heat in the combined model solution results from two factors. First, residential space heat demand is assumed to grow at the same rate as GNP *The 198.5 Reference Energy System in the Sourcebook is used for comparison. 
Table 4

1985. Total Energy Demands, $10^{15}$ BTU

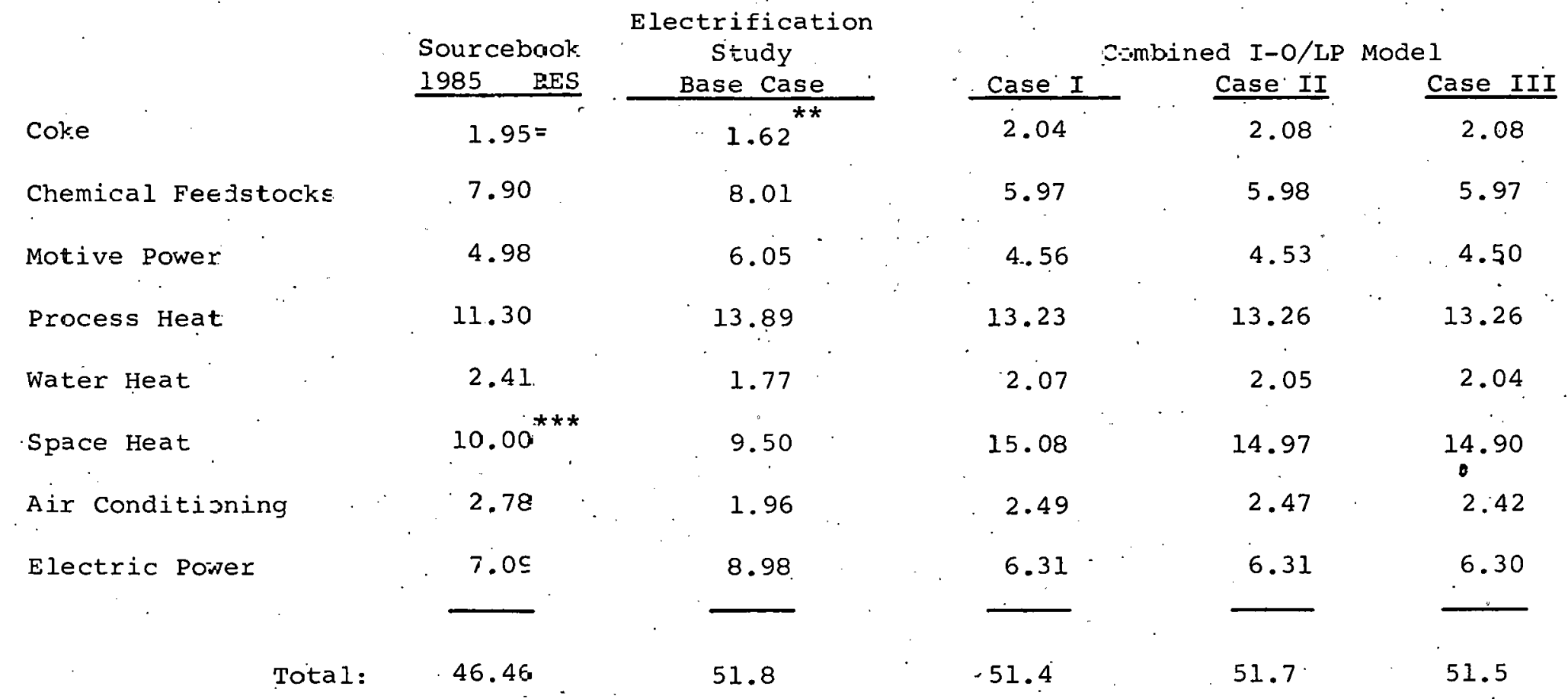

* This is equivalent to $2.81 \times=0^{15}$ Btu of cleaned coal in the RES $\exists$ oing to blast furnaces.

** This is ec divalert to $2.34 \times \underline{15}$ Btu of cleaned coal in the Electrification study going to blast furraces.

*** Space heat demand in the soursebook is multiplied by 1.58 to achieve comparability with the definition of space heat demand ised in the other studies. 
between 1967 and 1985 in the combined model-an unrealistically high rate. This biases total space heat demand upward. Second, the combined model includes industrial sector demands for space heat which are not included in Sourcebook and Electrification Study demands.

There is clearly a need to develop techniques for projecting changes in I-O energy product coefficients and GNP components of energy demand over time... The need is greatest for those demands which are expected to grow at rates significantly different from GNP-space heat, air conditioning, water heat and motive power. Development of appropriate techniques has been initiated, and they will be used in future applications of the combined model. 
C. Capital Investment

The total level of investment needed to support domestic production in Case I is $\$ 199.0$ billion. For Case II, doubled oil price, capital investment is $1.7 \%$ larger, \$202.4

billion. Comparing Case III with Case II, restricted oil imports, capital requirements are $3.7 \%$ greater, totaling $\$ 209.9$ billion.

Capital requircments can he partitioned into those for energy sectors and thuse for non-energy sectörs. Elleyy sector requirements increase over the three cases from $\$ 47.8$ to $\$ 51.5$ to $\$ 60.1$ bilition. Non-energy sector requirements, on the other hand, show less than one percent vartatiul over tho throe rases. If in fact the higher oil price initiated by OPEC in late 1973 persists through 1985, investment in domestic energy facilities will be significantly greater over this period. Policies designed to reduce oil imports beyond that which would occur as a diroct result. of their higher price will further increase domestic energy investment. The increase in capital expenditures in the energy sestors ander either of the Lw jolicice analyzed is large enough to affect the cost of capital within the capital market and to divert some of the country's resources from the production of personal consumptiou yoodg and subvirea.

Which energy sectors, then, will experience the greatest growth in capacity? Tablc 5 indisates the Mean Annual Growth Rates from 1967 to 1985 for the energy supply sectors under 
Table 5

Mean Growth Rates for

Energy Supply Sectors.

\begin{tabular}{|c|c|c|c|c|}
\hline \multicolumn{2}{|r|}{ Sector } & \multicolumn{3}{|c|}{ Mean Annual Growth 1967-1985,\% } \\
\hline & & Case I & Case II & Case III \\
\hline 1 & Coal & -0.3 & 1.2 & 2.7 \\
\hline 2 & Crude Oil and Gas & 0.5 & 0.5 & 0.9 \\
\hline 6 & Refined Oil Products & 1.1 & 0.9 & 0.8 \\
\hline 7 & Pipeline Gas & 1.3 & 1.3 & 1.3 \\
\hline 9 & Fossil Electric & -0.9 & 1.1 & 2.7 \\
\hline 10 & LWR Electric & 32.6 & 32.6 & 32.6 \\
\hline 12 & Hydroelectric & 5.7 & 6.3 & 6.3 \\
\hline
\end{tabular}


Case I, Case II and Case III. The most significant increases appear in the Coal and Fossil. Electric sectors. * The coal sector, which had a negative growth rate of $-.3 \%$ for case I has case II and Case III annual growth rates of $1.2 \%$ and $2.7 \%$ respectively. Similarly, the growth rate for Fossil

Electric changed from $-0.9 \%$ in case $I$ to a positive growth late of $1.1 \%$ for s.ase. II and $2.7 \%$ in Case III. Annual growth rates for other energy supply sectors such as fipclino Gas and LWR Electric remain constant over the three cases. The only energy supply sector to show a decline in mean annual growth as compared with Case I growth was the Refined oil Products sector. The remaining two energy supply sectors, Crude Oil and Gas and Hydroelectric had relatively small increases in annual growth rates for Case II and Case III.

Thus, if OPEC's policy of maintaining oil at the post ombargn price continues, or if the U.S. Carries out its policy to further reduce oil imports, capital investment in energy will

primarily be larger in the cual and coal steam electric generating sectors, under the assumption that 1985 nuclear generating capacity cannot be increased.

*All of the increase in the fossil electric sector is for coalfired plants. 
D. Composition of output in the Non-Energy Sectors

This section describes the major changes in composition of output for the two policies analyzed.

For Case II versus Case I, doubled oil price, the sectors with the largest increases in total output over case I levels are water transportation with a $5 \%$ increase and iron and ferroalloys ores mining with $4 \%$. All other non-energy sectors had increases or decreases in output of $0-3 \%$. Table " 6 shows changes in output between Case II and Case I for selected sectors.

Comparison of Case III with Case II levels of output, restricted oil imports; shows greater degrees of change. The most significant increases in output are in new construction and capital goods sectors. Residential construction output in Case III increases $3.6 \%$ over the Case II level. New construction for non-residential buildings and public utilities both increase $2.6 \%$. Outputs of most capital goods sectors surh, as construction, mininy and oll field machinery and equipment, materials handling equipment, special industrial. machinery equipment and heating, plumbin: and faisicated structural metal products increase by at least $2 \%$. The most significant decreases in output occur in the water transportation and pipeline transportation sectors. Table 7 shows changes in output between Case III and Case II for selected non-energy sectors, 
TABLE 6

SELECTED CHANGES IN OUTPUT, \%

CASE II VS.' 'CASE I

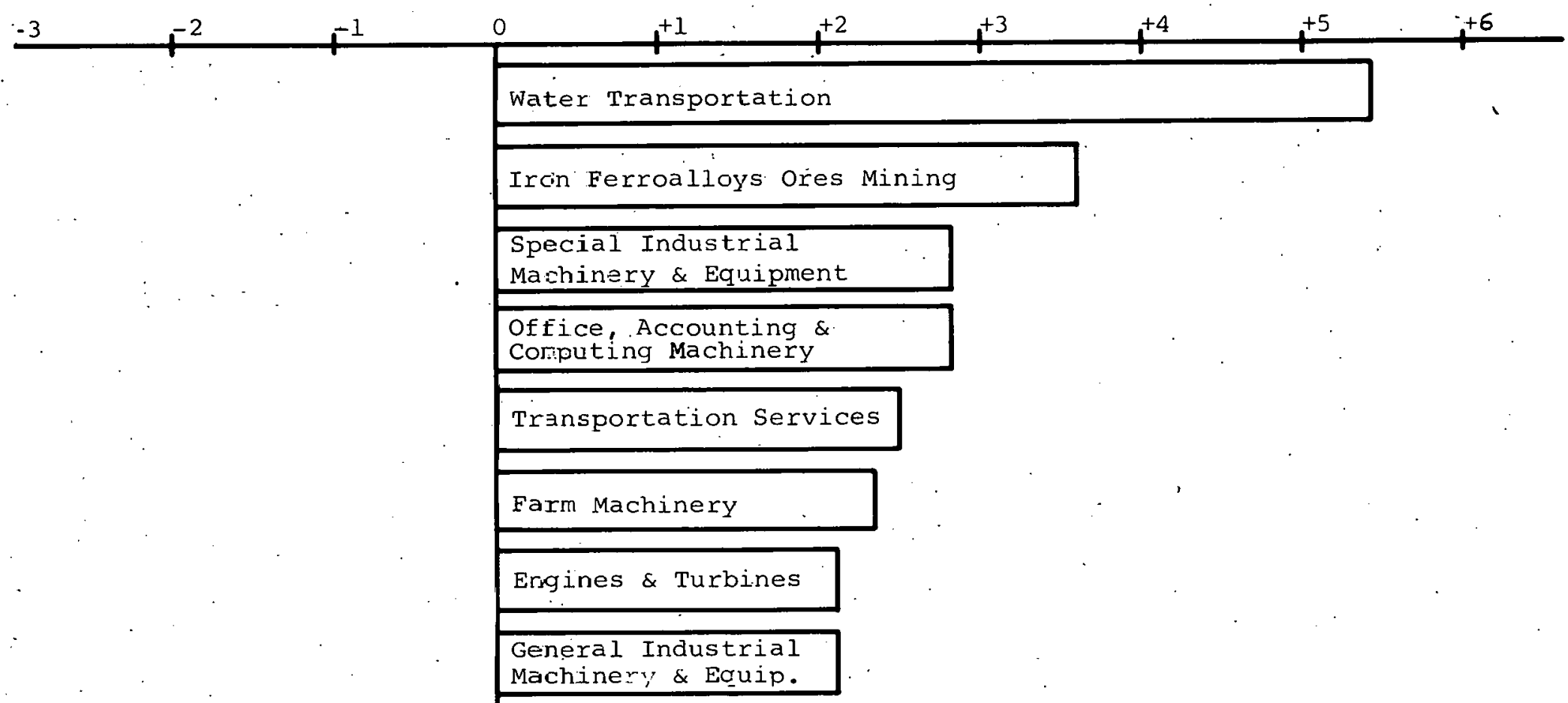

Ftwr, oth

Lthr Prod.

Food \& Rin-

Jred Prod.

Main.\& Re-

pair-Resid.

Apparel 
TABLE $\cdot 7$

SELECTED CHANGES IN OUTPUT, \%

CASE III VS. CASE II

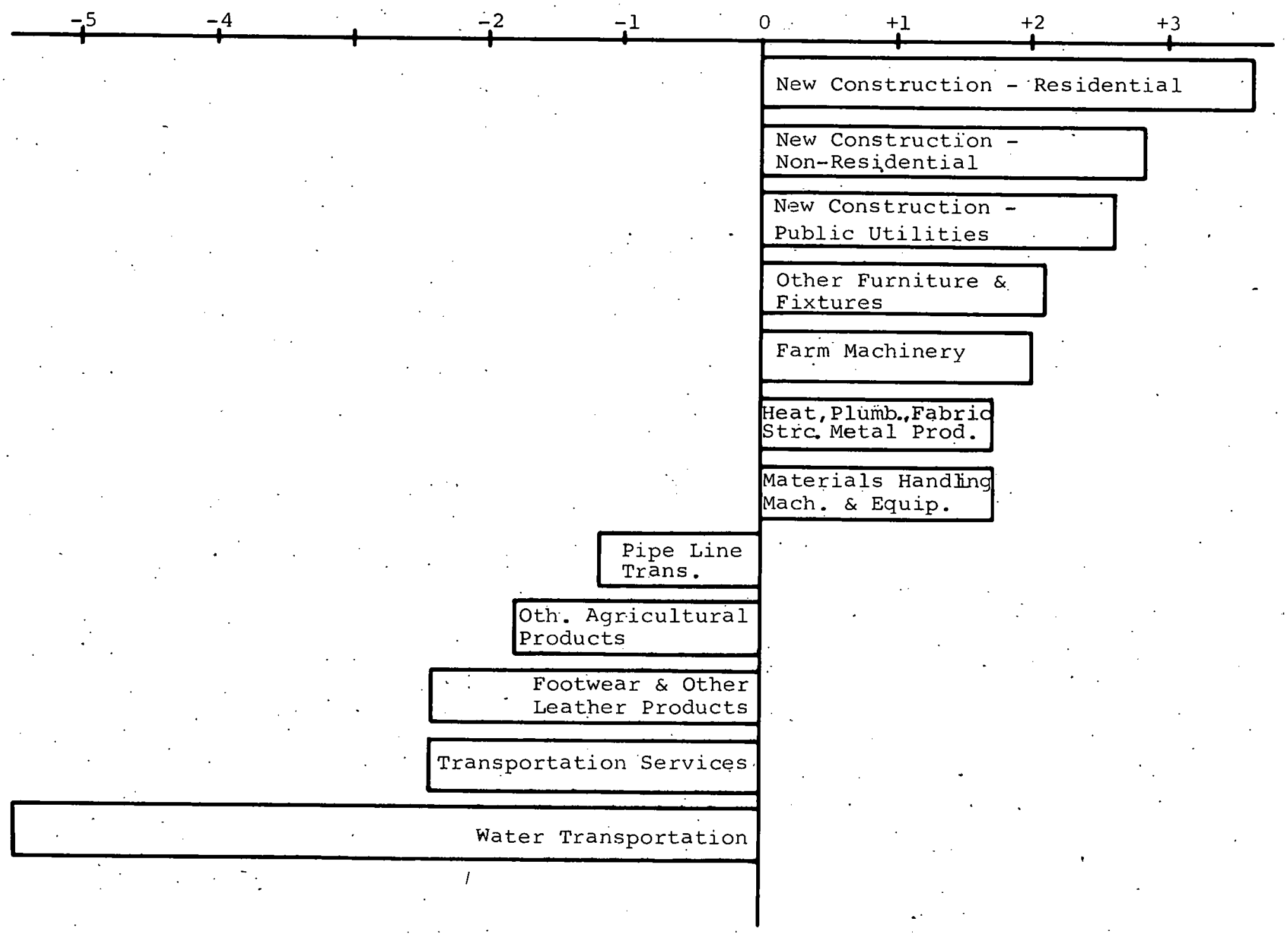


E. Employment Distribution

As the composition of total output changes for each of the three cases, there is also a change in the distribution of labor among the sectors. Using the solution vector of total output along with a "labor coefficient" vector which gives man-years per dollar of output for each sector, it is possible to calculate the associated employment distributions for each case.

Case II represents the situation in which the ojl cartel maintains doubled oil prices while the U.S. continues preoil cartel import policy. The resulting total 1985 employment in the domestic energy supply sectors increases by 191,000, or $10 \%$, over the Case I level to approximately 2.03 million man-years. Sectors having net decreases in employment of qreater than 10,000 man-years include: food and kindred products $(30,000)$, wholesale and retail trade $(229,000)$; medical and educational services $(163,000)$, and apparel $(36,000)$. These decreases reflect the smalles proportion of GNP gring to personal consumption expenditures. in Case II. Increases of greater than 10,000 man-years occur in the following sectors: New Construction $(65,000)$, Cual $(43,000)$, Hydselestric $(22,000)$, Fossil Electric $(132,000)$, and General Industrial Equipment $(13,000)$. All capital equipment. supply sectors have increased levels of employ- 
ment for Case. II, in response to increased total investment in 1985 under Case II. The large increase in employment for the aggregated new construction sectors reflects the need for additional industrial plant capacity and public utility construction for increased domestic coal use.

Comparison between Case II and Case III employment levels indicates the effects of the specific oil policy to cut oil imports in half. For Case III total employment in the energy supply sectors rises an additional 224,000 man-years from the Case II level to a total of 2.24 million. All capital equipment supply sectors have increased employment levels in accordance with the higher level of capital investment required for Case III outputs. The energy supply sectors which show the greatest net increases in employment for case III are coal, having a 54,000 man-year increase and Fossil Electric, increasing by 150,000 from case II to case III. This is the result of substitution of domestic coal and electricity production for previously used foreign nil imports. Non-energy sectors which show major changes in employment levels. for Case III include. New Construction, increasing by 145,000 man-years, wholesale and retail trade with a 132,000 man-years decrease, and medical and educational 
services having a .79,000 decrease in man-years. For Case III, there is clearly an even greater reduction in expenditures, and therefore employment, in the personal consumption areas in order to compensate for the large amount of construction and capital formation necessary for the $: 4.1 \%$ increase in investment required for Case. III. The Refined Oil Products sector has a decrease of 2;000 man-years indicating the direct employment effect of the reduction of oil imports. 
IV. RECOMMENDATIONS

This analysis presents the first outputs from the 110 sector energy input-output model. Certain problems were, of course, discovered in specifying the model and in making analytical runs. The following recommendations are made in order to overcome problems which remain and to provide increased confidence in its use.

1. The difference in energy product demands predicted by the energy I-O model and those specified in the Sourcervok (1). commonly used energy demand projections, should be reconciled and definitional differences identified and recorded. 2. The energy I-O model should be validated by inserting 1967 parameters and prices. in the LP and comparing the combined model solution with historical 1967 I-O data.

3. Techniques should be developed for estimating 1985 energy product coefficients ( $A_{P S}$ and $A_{P I}$ submatrices) as a function. of technological change and relative energy price changes. Estimated 1985 coeffioiento as well as 1967 historical coefficients are available for use in all other parts of the A-matrix. 4. Imputed prices for energy supplies and products in the I-O should be calculated from the LP solution. This will permit adjustment of the entire $\mathrm{Y}$ vector in terms of dollars, and not a mixture of dollars and BTU's. 
5. A more recent set of total sectoral outpids than 1967 (preferably 1974) should be developed with which to more accurately estimate sectoral growth rates to 1985 .

6. Econometric estimation procedures should be developed to estimate that portion of energy product demands which are included in GNP. 


\section{REEERENCES}

1. Beller, M. (ed.), Sourcebook for Energy Assessment. Brookhaven National Laboratory Formal Report, BNL 50483

(December 1975).

2.'Beller, M., E.A. Cherniavsky, and K.C. Hoffman, Interfuel Substitution Study - The Role of Electrification. Brookhaven National Laboratory Informal Report, BNL 19522 (ESAG-17), (November 1.974).

3. Behling, D.J., Estimation of Final Demands and Current Input-Output Coefficients to 1985, BNL 20369 (August 1975).

4. Just, J., B. Borko and A. Ashmore, New Energy Technology Coefficients and Dynamic Energy Models, Energy Research and Development Administration, Report ERDA-3 (2 Volumes plus corrected tables) (January 1975).

5. Fisher, W.H. and C.H. Chilton, An Ex Ante Capital Matrix for the United States, 1970-1975, Battelle Memorial Institute, Columbus Laboratories (March 31, 1971).

6. Behling, D., W. Marcise, M. Swift and R.G. Tessmer, Jr., A Two-Level Iterative Model for Estimating Interfuel Substitution Effects, BNL \#19363. Paper presented at Summer Computer Simulation Conference, San Francisco.(July 1975).

7. Bullard, C.W. and R.L. Knecht, End Uses of Energy in the U.S. Economy (1967). CAC Document No. 145, University of Illinois at Ur'oana-Champaign (January 1975).

8. The Inpixt-Output Structure of the U.S. Economy - 1967. Survey of Current Business, Vol. 54, No. 6, pp. 24-56 (February.. 1974).

9. Tessner, R.G., Interface Equations for 110 Sector InpidtOutput Model, BNL \#20354 (July 1975).

10. Cherniavsky, E.A., Brookhaven Energy System Optimization Model. Brookhaven National Laboratory Topical Report, BNT, \#19559 (December 1974). 


\section{Appendix A}

Combined model. Inpul Dala and nintput

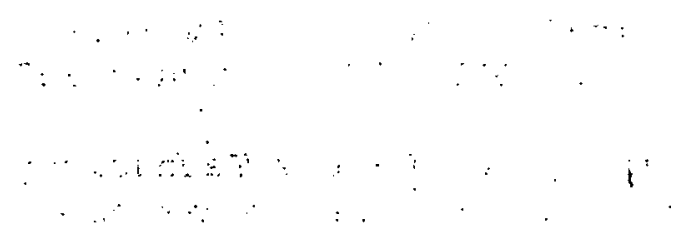


TABLE $A-1$

LP Supply Constraints, $10^{15}$ BTU

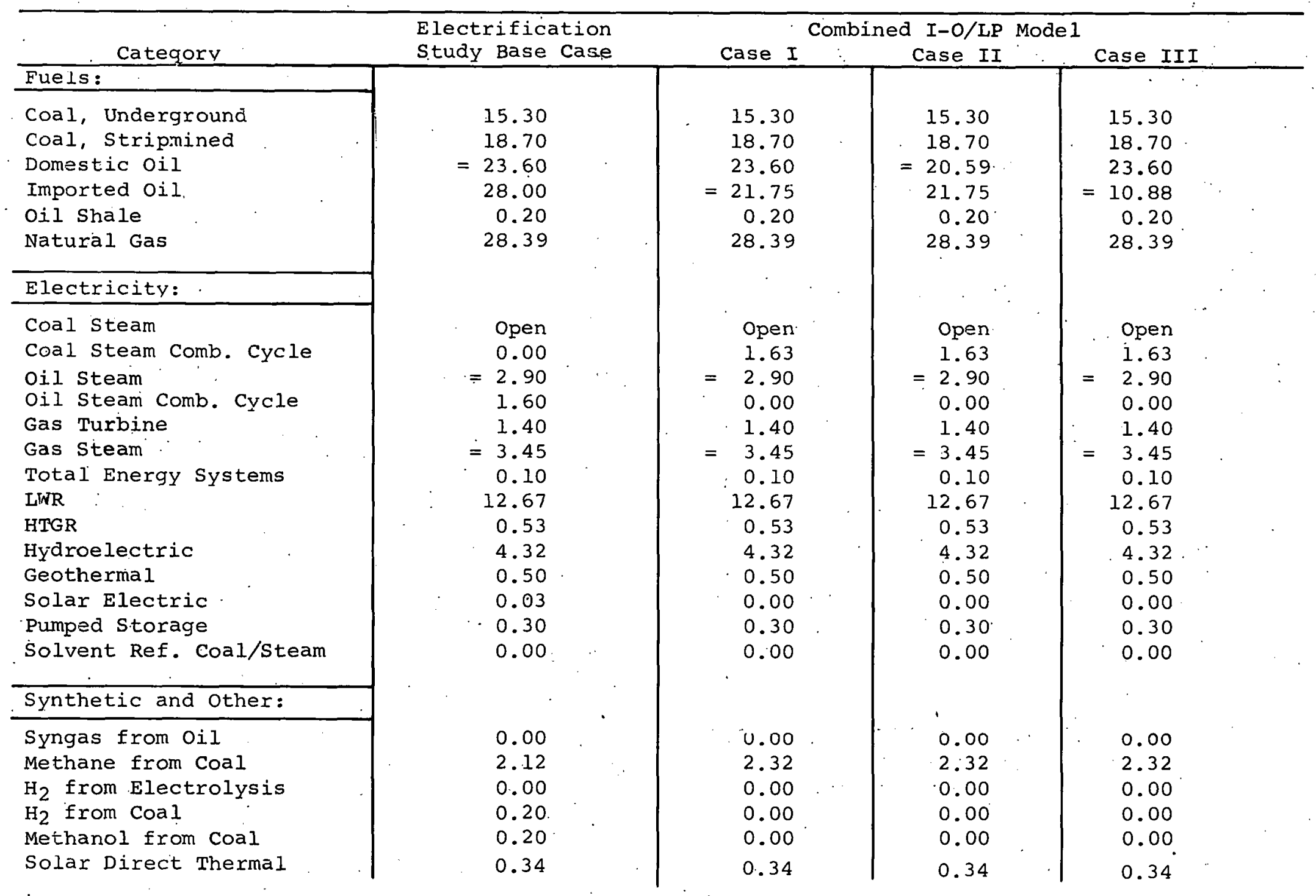

* "Equality" constraints are indicated by an = sign. All others are "less than or equal" constraints. 
TABLE $A \div 2$

LP Solutions, $10^{15}$ " BTU

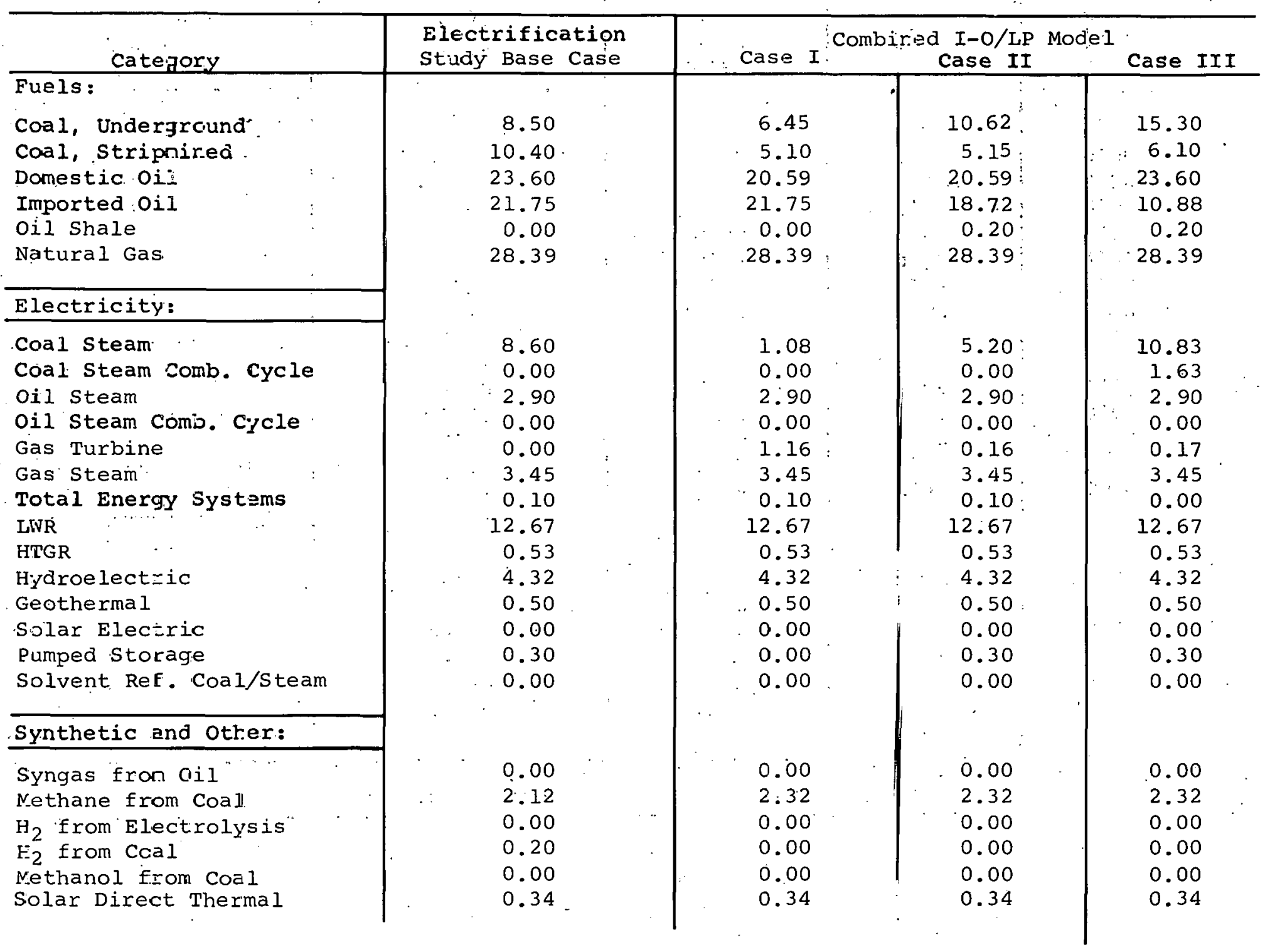


Adjusted Components of 1985. Gross National Product

\section{Component}

Personal consumption expenditures energy products. $10^{15} \mathrm{BTU}$ non-energy sectors, $10^{9}$ \$

Capital investment non-energy sectors, $10^{9}$ \$

Fedèral government, deferse energy products, $10^{15}$ BTU non-energy sectors, 109 \$

Federal government, non-defense energy products, $10^{15}$ BTU nor-energy sectors, $10^{9} \$$

State ard lccal government energy products, $10^{15}$ BTU non-energy sectors, $10^{9}$ s

Inventory change

$$
\text { - energy supplies; } 10^{15} \text { BTU }
$$

non-energy sectors, $10^{9}$ s

Exports

energy supplies, $10^{15} \mathrm{BTU}$ non-energy sectors, 109 s

Competitive imports

energy supplies, $10^{15}$ BTU

\section{Case I}

12.6

885.9

199.0

0.4

33.5

0.2

19.1

1.7

79.0

0.2

14.3

3.4

97.8

$-26.6$

$-54.9$

\section{Case II}

12.4

872.3

202.4

0.4

33.5

0.4

33.5

0.2

19.1

19.1

1.7

79.0

79.0

0.2

14.3

14.3

3.4

97.8

105.1

$-23.8$

$-54.9$
$-16.3$

$-54.9$

*Expressea in real terms (1967 constant dollars and physical Btu's). GNP purchases of \$119.2 billion excluded from the Einal demand vector used.with the combined model are not shown in this table. 
Table A-4

Capital/Output Ratios For Input-Output Model

Sector

Coal

Crude oil \& gas

Shale oil

Methane from coal

Solvent refined coal

Refined oil products

Pipeline gas

Coal combined cycle electric

other fossil electric

LWR electric

ITTCR olostrin

IIydroclectrif

Ore reduction feedstocks

Chemical feedstocks

Motive power

Process heat

Water heat

Space heat

Air conditioning

Electric power

Livestock and livestock products

Other agricultural products

Forestry and fishery products

Agricultural, forestry and fishery services

Iron and ferroalloys ores mining

Nonferrous metal ores mining

Stone and clay mining and quarrying

Chemicals and fertilizer mineral mining

New construction, residenclal buildings

New construction, nonresidential buildings

New construction, public utilities

New construction, highways

New construction, all other

Maintenance and repair construction, residential

Maintenance and repair construction, all other

Ordnance and accessories

Food and kindred products

Tobacco manufactures

Broad and narrow fabrics, yarn and thread mills

Misc. textile goods and floor covering

Apparel

Misc. fabricated textile products

Lumber and wood products, except cunlaimeis

Wooden containers

Ilouschold furniture

Other furniture and fixtures

Paper and allied jroducte oxcept strinainers and boxes

Paperboard containers and boxes

Printing and publishing

Chemicals and selected chemical products

Plastics and synthetic materials

Drugs, cleaning and toilet preparations

Paints and allied pruducts

Paving mixtures and blocks

Asphalt felts and coatings

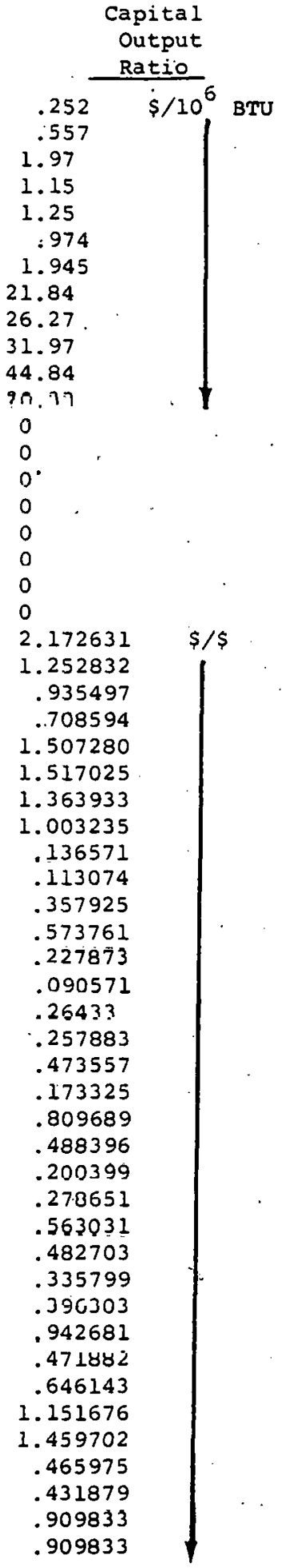


Table A-4 (cont'd)

Capital

Sector

Output

Ratio

Rubber and miscellaneous plastics products Leather tanning and industrial leather products Footwear and other leather products

Glass and glass products

Stone and clay products

Primary iron and steel manufacturing

Primary nonferrous metals manufacturing

Metal containers

Heating, plumbing and fabricated structural metal products

Screw machine prod., bolts, nuts, etc. \& metal stampings Other fabricated metal products

Engines and turbines

Farm machinery

Construction, mining, oil field machinery, equipment

Materials handling machinery and equipment

Metalworking machinery and equipment

special industry machinery and equipment

General industrial machinery and equipment

Machine shop products

Office, computing and accounting machines

Service industry machines

Elec. trans. \& dist, eq. \& elec. industry apparatus

Household appliances

Electric lighting and wiring equipment

Radio, television and communications equipment

Electronic components and accessories

Miscellaneous elec. machinery, equipment \& supplies

Motor vehicles and equipment

Aircraft and parts

Other transportation equipment

Professional, scientific \& controlling inst. \& supp.

Optical, opthalmic, \& photographic equip. \& supp.

Miscellaneous manufacturing

Railroads and related services

Local, suburban \& interurban highway pass. trans.

Motor freight transportation and warehousing

Water transportation

Air transportation

Pipe line transportation

Transportation services

Communications except radio \& television broadcasting

Radio and TV broadcasting

Water and sanitary services

Wholesale and retail trade

Finance and insurance

Real estate \& rental

Hotels \& lodging; pers. \& repair serv., except auto repair

Business services

Automobile repair \& services

Amusements

Medical, educ. services \& nonprofit inst.

Federal government enterprises

State and local government enterprises

Business travel, entertainment \& gifts

office supplies
$.537163 \quad \$ / \$$

.239616

.167655

.711399

.866195

1.326454

.438728

.422197

.473663

.449835

.491376

.412413

.332401

.343139

.352319

.574835

.560392

.497869

.611867

.797522

.340867

.4504

.414493

.230721

.271688

.371999

.310085

.284464

.249017

.383887

.301494

.542486

.417585

4.102074

.429891

.31522

2.360189

1. 129331

6.97954

.520187

4.227327

.473309

1.494666

1.063951

.275388

.040004

1. 224099

.380553

2. 981520

.873775

1.291188

0

0

0 
Sector

coal

Crude oil \& gas

Shale oil

Methane from coal

Solvent refined coal

Refined oil products

pipeline gas

Coal combined cycle electric

other fossil electric

LWR electric

HTGR electrle

Hyaroelectric

ore reduction reedstulid

Chemical: feeds toćks

Motive power

Process heat

Water heat

Space heat

Air conditioning

Electric power

Livestock and livestock products

other agricultural products

Forestry and fishery products

Agricultural, forestry and fishery services

Iron and ferroalloys ores mining

Nonferrous metal ores mining

stone and clay mining and quarrying

Chemicals and fertilizer mineral mining

New construction, resiaential buildings

New construction, nonzesidential buildings

New construction, public utilities

New construction, highways

New construction, all other

Maintenance and repair construction, residential

Maintenance and repair construction, all other

oranance and accessuries

Fuou and kindren products

Topacco manufactures

Broad and narrow fabries, yajis ond tuxsar mi.t.l.s

Misc. textile goods and floor covering

Apparel

Misc. fabricated textile products

Tiumber and wood products, except containers

wooden containers

Household furniture

other furniture and fixtures

paper and allied products except containers and boxes

paperboard containerg and boxes

Printing and publishing

Chemicals and selected chemical products

plastics and synthetic materials

Drugs, cleaning and toilet preparations

paints and allied prodices

Paving mixtures and blocks

Asphalt felts and coatings

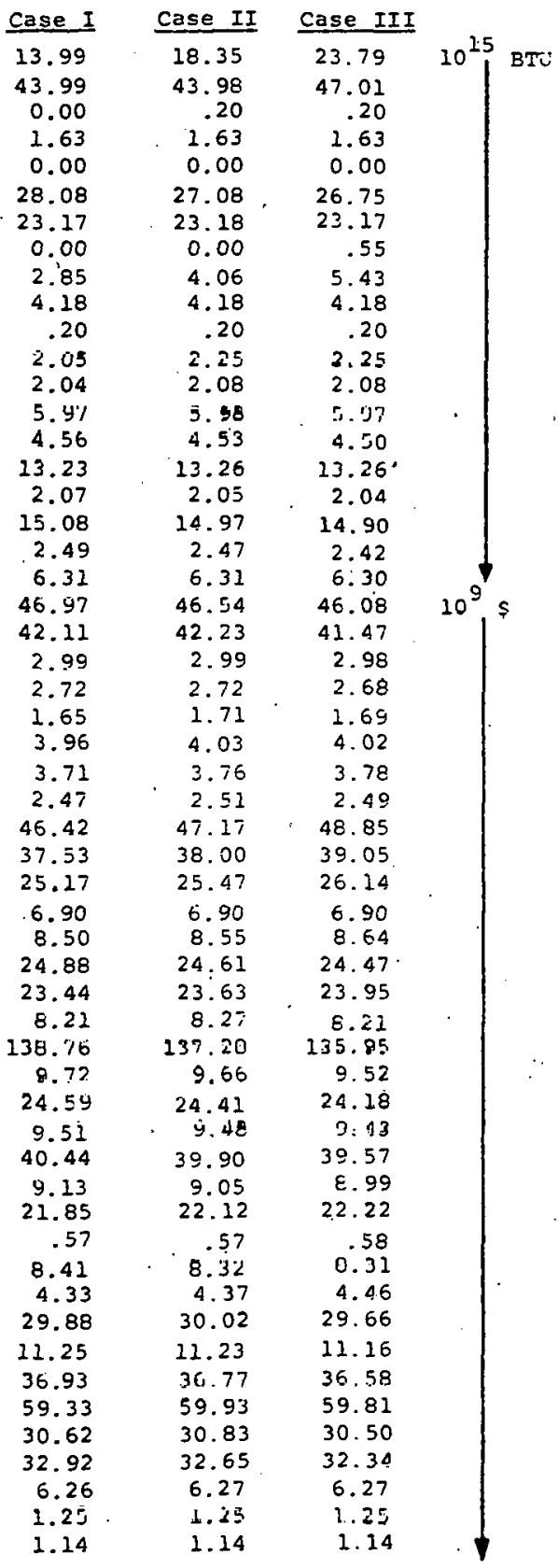




\section{Sector}

Rubber and miscellaneous plastics products

Leather tanning and industrial leather products

Footwear and other leather products

Glass and glass products

Stone and clay products

Primary iron and steel manufacturing

Primary nonferrous metals manufacturing

Metal containers

Heating, plumbing and fabricated structural metal products

Screw machine prod., bolts, nuts, etc. \& metal stampings

Other fabricated metal products

Engines and turbines

Farm machinery

Construction, mining, oil field machinery, equipment

Materials handing machinery and equipment

Metalworking machinery and equipment

Special industry machinery and equipnent

General industrial machinery and equipment

Machine shop products

Office, computing and accounting machines

Service industry machines

Elec. trans. \& dist. eq. \& elec. industry apparatus

Househole appliances

Electric lighting and wiring equipment

Radio, television and communications equipment

Electronic components and accessories

Miscellaneous elec. máchinery, equipment \& supplies

Motor vehicles and equipment

Aircraft and parts

Other transportation equipment

Professional, scientific \& controlling inst. \& supp.

Optical, opthalmic, \& photographic equip. \& supp.

Miscellaneous manufacturing

Railroads and related services

Local, suburban \& interurban highway pass. trans.

Motor freight transportation and warehousing

Water transportation

Air transportation

Pipe line transportation

Transportation services

Communications except radio television broadcasting

Radio and TV broadcasting

water and sanitary services

Wholesale and retail trade

Finance and insurance

Real estate \& rental

Hotels \& lodging; pers. \& repair serv., except auto repair

Business services

Automobile repair \& services

Amusements

Medical, educ. services \& nonprofit. inst.

Federal government enterprises

State and local government enterprises

Business travel, entertainment \& gifts

Office supplies
Case I

42.70

.30

3.40

6.42

17.33

39.26

42.04

6.51

24.34

10.88

23.6 .1

10.59

5.29

10.77

5.34

12.42

7.85

15.55

6.67

21.83

17.79

22.57

11.98

10.06

35.59

22.80

7.14

97.64

27.80

19.13

11.85

14.85

16.62

14.55

4.35

33.15

5.35

30.93

1.67

1.22

56.53

3.7 .4

5.49

315.80

96.31

203.99

30.77

119.12

24.05

14.37

107.25

16.31

11.58

19.07

3.60
Case II

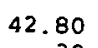

.30

3.37

6.44

17.53

39.85

42.68

6.47

24.63

11.01

23.84

10.81

5.41

11.13

5.44

12.65

8.07

15.88

6.75

22.45

18:02

22.97

11.90

$10: 16$

35.81

23.18

7.19

97.98

28.34

19.19

12.01

15.03

16.55

14.74

4.31

33.27

5.64

31.06

1.65

1. 25

56.25

3.74

5.46

313.50

95.38

201. 13

30.47

119.02

23.85

14.28

105.79

16.26

11.53

19.08

3.60
Case III

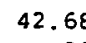

.30

3.29

6.39

17.80

39.91

42.71

6.42

25.05

10.96

23.87

10.78

5.52

11.16

5.53

12.72

.8 .08

15.98

6.74

22.45

18.17

23.20

11.84

10.22

35.83

22.99

7.17

97.78

22. 12

19.28

11.99

14.92

16.42

1.4 .85

4. 30

33.15

5.33

30.75 .

1.63

J. 2 ?

56.07

3.73

5.44

312.18

94.91

200.65

30.20

118.79

23.75

14.12

105.08

16.21

11.48

19.08

3.60 
Table A-6

Alignment $0 \overline{-}$ BNL 110 with Other Classification Systems

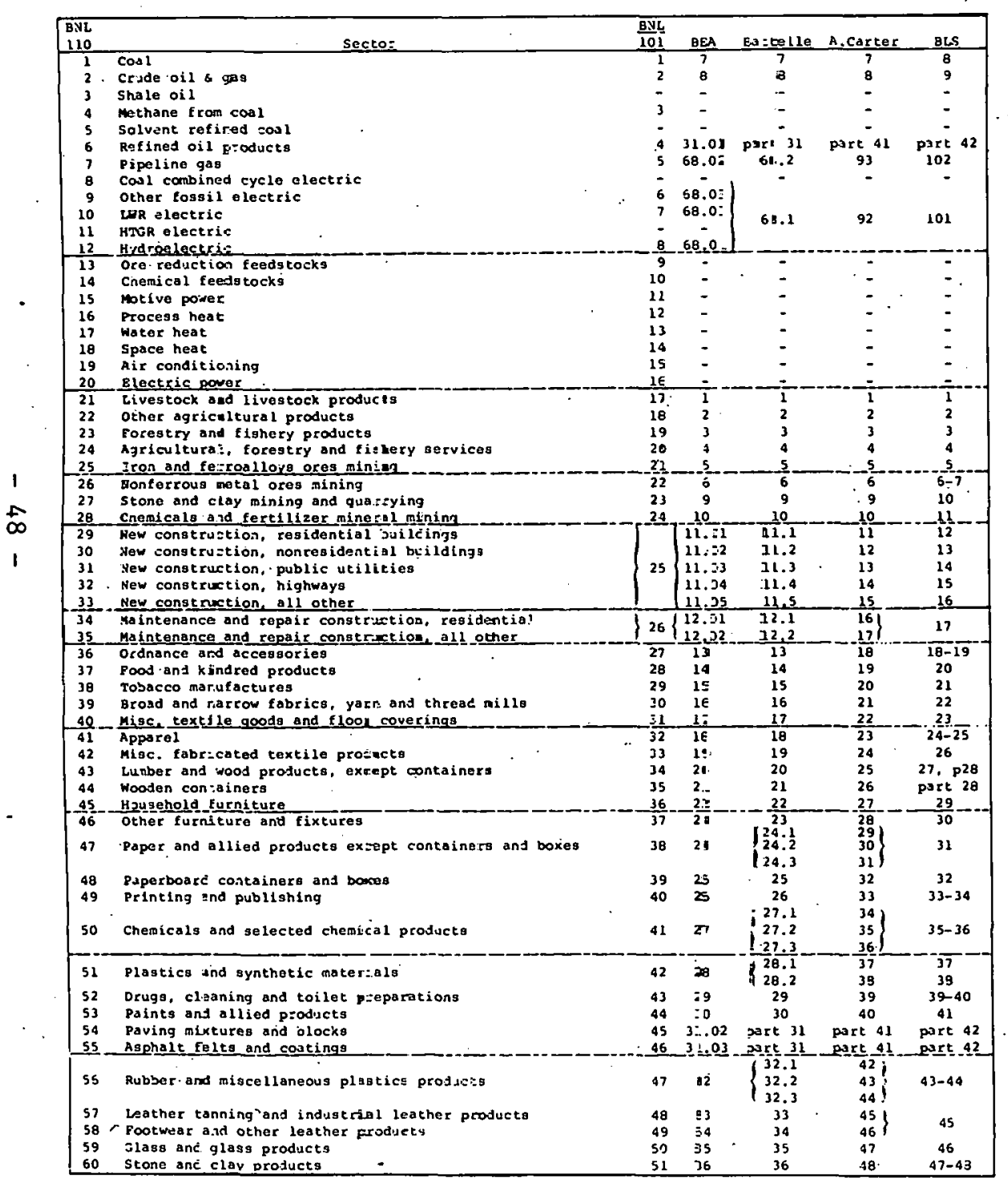

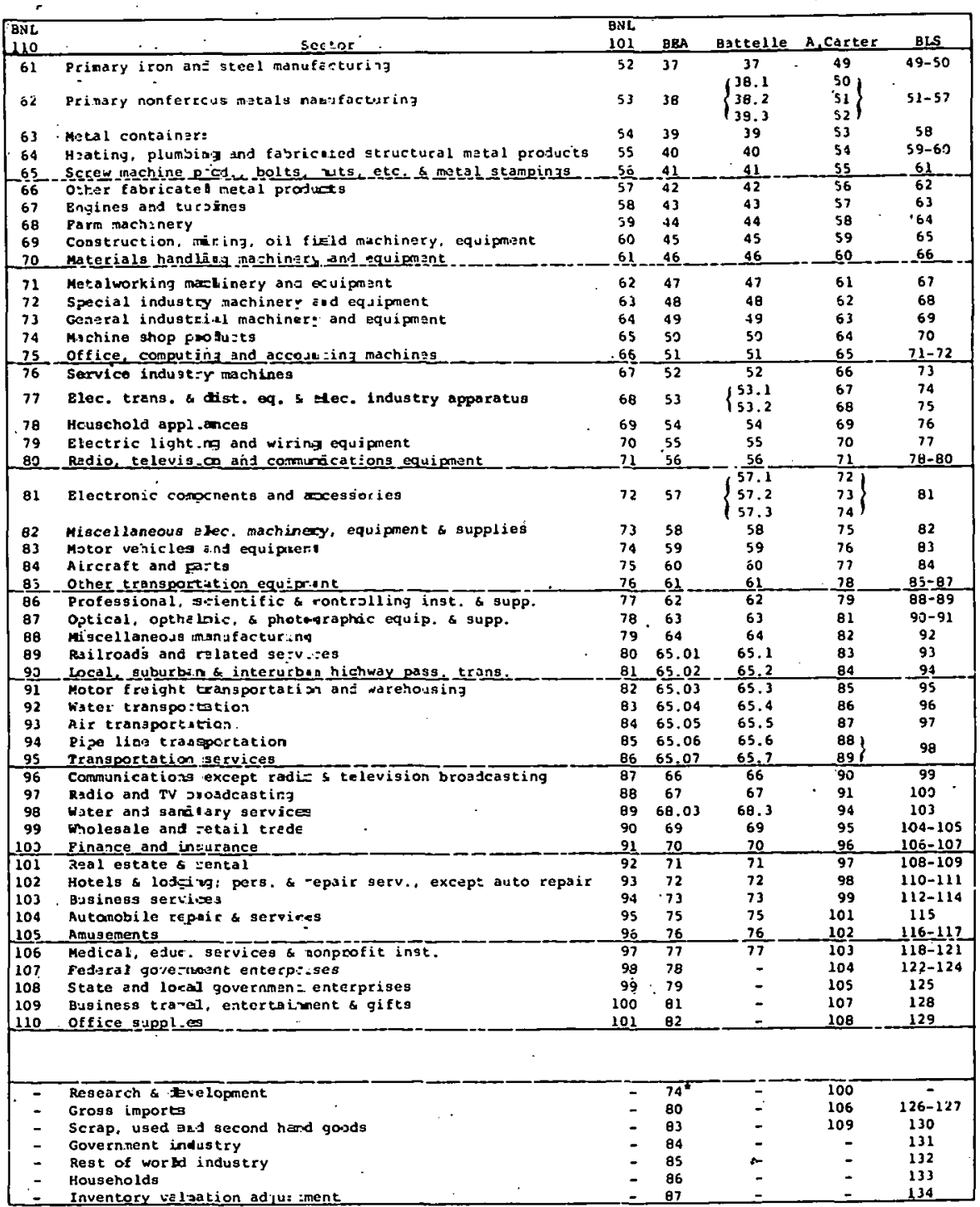

.E1iminated as a separste sector by BEA in the 1963 and 1967 studies. 
Appendix B. Estimation of Capital Investment Requirements. The 1985 GNP estimate used as a basis for model runs (3) contains estimates of how much capital equipment has to be supplied by those sectors which produce capital goods. These figures are contained. in the GNP component entitled Gross Private Fixed Capital Formation, GPFCF. Using a solution vector of total outputs from a model run and what are called "capital/output ratios" and a "capital replacement vector," one can estimate how much capital equipment is required in order to support the indicated growth in output from some historical year.

Capital investment needs by energy sectors are generally large, and these requirements will increase significantly as domestic energy supplies are substituted for foreign energy supplies. In order to capture the economic impact of this change as oil imports were reduced, capital reguirements were estimated and compared with the GNP estimate of capital equipment supni,ied. The GNP component, GPFCF, was then adjusted to obtain consistency between the level of investment required and the amount supplied. A compensating adjustment was made in personal consumption expenditures in order to maintain a constant real GNP, and the modified GNP vector used to obtain *AlI GPFCF. components of final demand for each sector were adjusted by the same proportional difference. 
a new combined model solution. *

Following is a description of the use of capital/output ratios and a capital replacement vector in estimating investment requirenents for the 1985 base case run.

An annual growth rate in output $g(i)$ is determined for each sector, by comparing levels of output for 1967 with those given by the sulution in the $x_{85}$ vector; and solving the following formula for each $g(i): x_{85}(i)=(1+g(i))^{18} \cdot x_{67}(1)$. Once the average growth rate over this 18 year period, 1967-1985, is determined, it is possible to calculate the amount of investment needed during 1984-1985, $I_{84-85}$ ' to support this level of growth. Let $\mathrm{K}_{t}$ represent the capital stock in year $t_{\text {; }}$ let $c$ be the capital/output ratio, $c=\frac{K_{t}}{x_{t}}$; and $\delta$ the capital replacement rate. Then the endogenously determined level of gross investment for each sector from 1984. to 1985 is determined by:

$$
\begin{aligned}
I_{84-85} & =K_{85}-K_{84}+\delta K_{84} \\
I_{84-85} & =C \cdot x_{85}-c \cdot x_{84}-\delta \cdot C \cdot x_{84} \\
& =c \cdot x_{85}-C \cdot(1 \ldots \delta) \cdot Y_{84}
\end{aligned}
$$

\footnotetext{
*This was actually all iterativc procedure granining one or two arditional capital requirement comparisons, GNP adjustments, and subsequent combined model runs. This iterative procedure is continued until the level of capital equipment supplied, as contained in the $Y$ vector of final demand, is "equal" at some specified level of accuracy to the estimated capital equipment required.

**Capital/output ratios used for this study are tabulated in Appendix A.
} 


$$
\begin{aligned}
=c \cdot x_{85}-c \cdot \because(1-\delta) \cdot \frac{x_{85}}{(1+g)} \\
I_{84-85}=c \cdot x_{85} \cdot\left[1-\frac{1-\delta}{1+g}\right] \text { for each sector; } i
\end{aligned}
$$

Then a comparison is made between total investment requirements, $\sum_{i} I_{84-85}$, and capital supplied, total GPFCF in the $Y$ final demand vector. When the total capital investment given in the final demand vector is lower than that necessary to support the $\mathrm{x}_{85}$ vector, the GPFCF component of final demand. is increased to equal $\sum_{i} I_{84-85}$ and the PCE component of final demand is adjusted downward by the same amount. This is one method of maintaining a constant "real" GNP and other adjustment mechanisms could be assumed.

The combined model is run a second time using the new Y vector. The new solution after this second run is checked to determine if the new level of capital equipment supplied is sufficient to support investment requirements consislent with the new solution vector of total outputs. This iterative procedure is followed until there is satisfactory agreement between the exogenous investment vector in final demand and those requiromonts calculated with capital coeffirients. 
The table below illustrates the converging solution of the case I run as capital investment supplied becomes consistent. with capital investment required.

\begin{tabular}{|c|c|c|c|c|}
\hline & $\begin{array}{l}\sum_{\mathrm{Y}} \mathrm{Y}(2, i), \text { or GPFCF } \\
\text { (capital investment } \\
\text { supplied) }\end{array}$ & $\begin{array}{l}\sum_{i} I_{84-85} \\
\text { (capital investment } \\
\text { required) } \\
\end{array}$ & Difference & \% Difference \\
\hline 1 & 211.76798 & 198.62091 & -13.14707 & $-6.2 \%$ \\
\hline un 2 & 198.62091 & 199.03736 & .41643 & $.2 \%$ \\
\hline Run 3 & 199.03736 & 199.02400 & -.01336 & $-.007 \%$ \\
\hline
\end{tabular}


Appendix C. GNP Standardization Techniques*

Aggregate real GNP was assumed to be constant over all

three cases analyzed. The reason for this was to standardize

on the estimates of the labor force, labor productivity and capital

productivity used for the forecast of 1935 GNP in (3). Since

the economic basis for the input-output model is long-term

dynamic equilibrium, resources of production can be assumed to

be perfectly mobile and short-term business cycle fluctuations

can be ignored. These conditions are consistent with asking

the question, "How will the composition of goods and services

produced by the economy shift over the long-run as the price of

oil increases and policies are introduced to decrease oil imports?", which is the central topic addressed by this report.

\section{Casè I}

For Case I only one adjustment in the composition of

GNP was required. Gross private fixed capital formation (GPFCF), which represents capital goods supplied by the economy in 1935 , was reduced ${ }^{*}$ to the amount of capital goods required, as estimated by capital coefficients from Datleile (b) and Mitre (4). Estimation of "required" capital is described in Appendix B. Personal consumption expenditures were "increased" ${ }^{* *}$ by the amount GPFCF" was reduced in order to maintain the same ieal GNe of \$1439 billion.

\footnotetext{
*The techniques described in this section were only applied to GNP purchases "included" in the combincd millel final demarid vector which total \$1319.9 billion. "Excluded" purchases (wages to employees not covered by sectors in model, non-competitive imports, and U.S. outside transactions) total \$119.2 billion, and they are held constant for all three cases.

**Each entry in the GPFCF vector was decreased in the same proportion. $* * *$ Each entry in the PCE vector was increased in the same proportiun.
} 


\section{Case II}

In Case II it is presumed that the price of oil remains at twice the level of that in Case I over the next ten years. With domestic oil supply held at the case I level, oil imports are $14 \%$ less and domestic coal production is $31 \%$ greater. Payment to foreigners for oil increases by \$15 billion, affecting the country's intcrnational balance of payments.

Foreignërs cal do three things willi the dulitimal dollars they get from us. They can directly buy more goods and services from us; they can hoard the dollars or buy U.S. financial assets (e.g. stocks and bonds) and real assets (e.g. land, buildings, factories), all of which would equal transfers in U.S. assets; and they can spend the dollars to obtain other currencies. If they do the latter, the value of the dollar will decrease relative to other currencies, and this dollar devaluation, in turn, will lcad to mnre U.S. exports and less U.S. imports.

For this analysis only one situation is analyzed - 100\% recycle of the additional U.S. foreign payments, with $50 \%$ of the dollars used for asset transfer and $50 \%$ used to purchase more U.S. exports. No adjustment in the components of GNP has to be made for the asset transter. Totnl cxports, however, have to be increased by $\$ 7.5$ billion. *

* Each entry in the export vector was increased in the same proportion. A vector of export good elasticities is also available for use when the change in composition of exports is important. 
- Although imports in monetary terms are larger for case II, they are less in real terms (less oil is being imported).

No change has yet been made in domestic production. But less imports in real terms means less goods available for consumption. In order to standardize on a single level of domestic production capacity, other GNP purchases must decrease by the amount that imports have dropped in real terms. For case II it is assumed that the entire adjustment is made in PCE purchases. Thus, individual consumers receive the direct effect versus federal, state, or local governments.

One more adjustment in GNP relative shares is required. Increased use. of domestic fuels means that more capital goods must be produced (more coal mines have to be opened and móre coal steam electric plants constructed, for example). Capital coefficients are used to estimate the new level and composition of required capital goods, and GPFCF increased accordingly. In accordance with the procedure described in Appendix B, PCE purchases are reduced in order to maintain the same real GNP.

In summation, composition of GNP purchases in Case II differs from that in case $I$ in the following ways:

1) Imports are greater in monetary, terms, but less in real terma; 
2) Exports are greater because of recycled foreign dollar payments;

3) GPFCF is greater because domestic production of energy must be substituted for oil imports;

4) PCE is less and reflects three things: the drop in imported goods available for domestic consumption, the shift to production of more export goods, and the shill to promrtion of more capital goods for the energy sector.

,

Price elasticities are ignored in these shifts.* These adjustmențs result in maintaining labor force participation, manpower requirements per unit of output, and capital requirements per unit of output consistent for all cases.

\section{Case III}

In case III it is presumed that the price of oil remains at twice tho level. of that in case I ovcr the next ten years. Also, policies are introduced to limit oil imports to half the Case I level. Payment to foreigners for imported oil is thus the same in Case III as in case I, and there is no aggregate change in the country's balance of paymonts.

$\mathrm{Ag}$ in case $\mathrm{II}_{\boldsymbol{g}}$ imports in real terms are less. Lower imports mean that fewer goods are available for domestic consumption. In order to standardize on a single level of domestic * Elasticities can be incorporated in the analysis. For the most part they are either unknown or would be rough estimates. 'The error introduced by ignoring them is of a second order effect in most sectors. 
productive capacity, it is assumed that the entire adjustment is made in PCE pirrchases as opposed to a drop in government pirchases. This drop in terms of 1967 prices totals $\$ 10.4$ billion from case I. As in Case II, upward adjustment is needed in GPFCF at the expense of PCE purchases in order to substitute domestic fuel production for the drop in imported oil.. The procedure described in Appendix $B$ is also used here.

In summation, composition of GNP purchases in Case III differs from that in case $I$ in the following ways:

1) Imports are the same in monetary terms, but less in real terms :

2) GPFCF is greater because domestic production of energy must be subtituted for oil imports;

3) PCE is less and reflects two things: the drop in imported goods available for domestic consumption, and the shift to production of more capital goods for the energy sector.

The breakdown on GNP for each of the three cases. is presented in Table A-3, Appendix A. All entries are in real terms with energy purchases expressed in physical units (BTU) and non-energy purchases expressed in constant 1967 dollars. 